\title{
Reforms in Rural Credit Cooperatives in India
}

\author{
Prof. Sharad N. Bansal ${ }^{1}$, Dr. Shradha H. Budhedeo ${ }^{2}$, Mr. Girish Thakkar ${ }^{3}$ \\ ${ }^{I}$ Department of Cooperative Management and Rural Studies Faculty of Commerce M S University of Baroda \\ Vadodara, Gujarat, India \\ ${ }^{2}$ Assistant Professor Department of Business Economics Faculty of Commerce M. S. University of Baroda \\ Vadodara, Gujarat, India \\ ${ }^{3}$ Teaching Assistant Department of Cooperative Management and Rural Studies Faculty of Commerce \\ M. S. University of Baroda Vadodara, Gujarat, India
}

\begin{abstract}
Rural credit cooperative system in India is world's largest rural financial systems. During the past over hundred years, these credit cooperatives have witnessed many successes and failures. For a long time, cooperatives have been plagued by numerous problems such as undue government interference, poor governance and management, high overdues and lack of deposits, financial indiscipline and accumulating nonperforming assets. In response to that, a nationwide reform and revival exercise was initiated by the Government of India in 2004. This paper examines the important features and strategies of these reforms in short-term rural credit cooperatives in India.
\end{abstract}

Key Words: Cooperative Credit Societies Act, Impairment, Primary Agricultural Credit Societies, Rural Credit Cooperatives, Task Force.

\section{Introduction}

The cooperatives, institutionalized in 1904 with the enactment of Cooperative Societies Act, have been an important part of the development of India for over 100 years now. It was born predominantly as a Government initiative to address the twin issues of farmers' indebtedness and poverty. The rural cooperatives in India have a complex structure, with institutions specializing in short-term and long-term credits. The shortterm rural credit cooperatives $[\mathrm{RCC}]$ in India were originally envisaged as a mechanism for pooling the resources of people with small means and providing access to different financial services.

The RCC in India has a three-tier federal structure. It comprises of Primary Agricultural Credit Societies [PACS] at the grass root village level, the District Central Cooperative Banks [DCCB] at the intermediate level; and at the top, State Cooperative Banks [SCB]. India has a well spread short-term credit cooperative network having more than 94,600 village-level PACS, with atleast one PACS for every six villages and total cooperative membership of over 126 million rural people, covering almost half of India's total population [GoI, 2006]. This makes the rural cooperative credit structure as one of the largest rural financial systems in the world. During the past over hundred years, the RCC have seen many successes and failures; nonetheless no other institution has brought so many people together for a common cause. The rural credit cooperative sector in India was plagued by numerous problems such as undue government interference, poor governance and management, high overdues and lack of deposits, financial indiscipline and accumulating nonperforming assets. In response to that, a nationwide reform and revival exercise was initiated by the Government of India in 2004.

The current study is exploratory in nature and has been organized into four sections. Section one of the paper traces the history of evolution of short-term rural credit cooperatives. Section two explores the reasons for impairment of RCC. Section three discusses the sequencing of action plan of reforms. The fourth section presents a summary of benchmark activities and status of implementation of the revival package.

\section{Phases In Evolution}

Since its inception in 1904, Indian short-term rural credit cooperative [RCC] sector has witnessed four significant phases in its progression [Vaidyanathan, 2004], illustrating the difficulties in striking a balance between self-sufficiency and state support of the sector [Li and Parmar, 2007]. The First Phase [1900-30] witnessed the government led active initiatives in promoting the credit cooperatives in the country with first Cooperative Credit Societies Act in India passed in 1904. Later in 1919, the 'cooperation' was made a provincial subject. The Second Phase [1930-50] began with the establishment of Reserve Bank of India Act in 1934, which played a major role in setting up, strengthening and promoting financially viable cooperative banks, central cooperative banks, marketing societies and primary agricultural credit societies in each province. However, there was a lull in the government policy towards cooperatives during this phase. This phase witnessed signs of sickness with a large number of cooperatives being saddled with frozen assets, because of 
heavy overdues. The Third Phase [1950-90] began with the beginning of India's planned economic era focusing on the need for rapid and equitable economic development. The cooperatives were once again viewed as vehicles of change in achieving these goals. During this period, the cooperative sector witnessed increasing state partnership and patronage in terms of equity, governance and management, resulting into the consequent erosion of cooperative discipline, credit worthiness and quality of portfolio of cooperatives. The focus was on expanding and reorganizing the state supported structure, without addressing the tasks of restoring and strengthening autonomy, mutual help and self-governance that are the cornerstones of genuine cooperatives [Vaidynathan, 2004].

The Fourth Phase [1990 onwards] was a turning point in India's economic history. This was a period of economic reforms which highlighted the increasing realization of the destructive effects of intrusive state patronage, politicization, and the consequent impairment of the role of cooperatives. In 2004, the Government of India constituted a Task Force [Vaidyanathan 2004] to formulate a practical and implementable plan of action to revive the rural cooperative credit structure.

\section{Causes Of Impairment}

Despite the phenomenal outreach and volume of operations, over the years, the health of rural credit cooperatives deteriorated significantly, experiencing low resource base, huge accumulated losses, borrower centered policies, high dependence on external sources of funding, government control, poor business diversification and low fund recovery. Almost half of the PACS turned into loss-making units. The share of PACS in agricultural credit at all India level fell down from 62\% in 1992-93 to $22 \%$ in 2007-08. Although organized on the principles of self-governance and self-reliance, the RCC faced fundamental policy, governance, legal and institutional problems that impaired its solvency, sustainability and efficiency [ADB 2010]. Vaidyanathan [2004] classifies these problems into three broad categories: governance, management and financial.

\section{A. Impairment of Governance}

In India, the cooperative credit institutions are largely credit based as against the joint functions of credit and thrift practiced by similar institutions in other parts of the world. The structure is, therefore, driven by borrowers at all levels, which creates a serious conflict of interest. Prior to the reforms, the impairment in governance was visible in weak governance of the credit cooperative societies, both internal as well as external. The former was represented by the composition of the boards of directors of the cooperatives and the reporting systems that were skewed towards state control. Besides the harmful effects of excessive politicization of these organizations, the cooperatives also lost their right to self-governance as they became greatly dependent on the state for its functions. Even the external regulation and supervision for the structure were not stringent enough.

\section{B. Impairment in Management}

The impairment in the management of RCC was a direct result of the impairment in governance. The various forms of interference of State Governments included deputation of officials to top positions in many banks, setting up common cadres for senior positions across all cooperative tiers, determination of staffing pattern, interference in the operational decisions of the cooperatives, and imprecise demarcation of governance and management functions.

\section{Impairment in Financial Performance}

The cumulative impact of poor governance and failure in management of cooperatives resulted into poor financial health and viability of the rural credit cooperatives in India. As these cooperatives have been borrower centric societies, the members were not risk bound and had limited accountability in the management of funds. Even the boards of management and their functionaries were not held accountable for laxity in granting and monitoring loans, poor quality of loan portfolios, high default rates and non-performing assets (NPAs). The reason for the losses could be traced mainly to the overall business levels and poor recovery position of each of the cooperative tiers. The recovery percentages for the system as a whole have been low continuously, making the system unsustainable without external injection of resources.

High transaction costs due to lack of standardized business models and overstaffing, and high risk costs due to low recovery levels led to the impairment of the rural credit cooperatives to a large extent. Another cause of financial impairment was the lack of scope for cross subsidization. At the higher tiers, there were overexposures to certain sectors of agriculture, which increased the covariance risks. The loan portfolios of the system as a whole was thus prone to greater risk and required provisions for risk costs, leading to extremely low and in many cases negative net margins. PACS did not follow well-defined risk provisioning norms. The lending rates of PACS have been state controlled, which despite being at higher risks were set well below the market rate. 


\section{Action Plan For Reforms}

Over the years, the growing concerns for impairment of credit cooperatives in rural India led to the setting up of the Task Force on Revival of Cooperative Credit Institutions, appointed by the Government of India in 2004 [Vaidyanathan 2004]. The committee recommended an action plan for reviving and revitalizing the rural credit cooperative institutions through legal measures necessary for facilitating this process. The task force submitted its report in February 2005, and after extensive discussions the revival package was implemented across the country in January 2006. The NABARD was made the implementing agency for the purpose. The revival package was a combination of legal and institutional reforms, capital infusion and technical support for capacity building. The implementation of the action Plan [ADB 2010] of the revival package was perceived to result in the emergence of a strong, self-reliant and well-knit network of rural cooperative credit system. The implementation of the revival package involved planning and execution of a series of action plans for:

A. facilitating legal, regulatory and governance framework

B. institutional reforms for sustainability

C. financial package and;

D. eligibility norms

\section{A. $\quad$ Facilitating Legal, Regulatory, and Governance Framework}

The state enacted Cooperative Societies Acts (CSAs) were amended for : providing full voting membership rights to all financial service users including depositors in cooperatives; removal of state interventions in all financial and internal administrative matters; capping the equity of participating states at 25 $\%$ and restricting participation of state in the boards of cooperative banks to one nominee; giving cooperatives the freedom to access loans from any regulated financial institution and not necessarily from its upper tier and similarly permitting to place their deposits with any regulated financial institution of their choice. State power was also limited from superseding boards, while due emphasis was given to ensuring timely elections. Cooperative banks were brought under the regulatory ambit of the Reserve Bank of India (RBI) and were subjected to prudential norms, including CRAR.

Besides, NABARD Act, 1982 and the Banking Regulation Act, 1949 were amended. With these amendments co-operatives were brought under the ambit of banking prudential norms of income recognition, capital adequacy, asset classification and provisioning. In an effort to strengthen the corporate governance framework, criteria's for CEOs and other directors were clearly defined and efforts were made to withdraw the state government nominees from the Board of PACS. Moreover, SCBs were also required to undergo a rating by an approved agency.

\section{B. Institutional Reforms for Sustainability}

Institutional reforms involved implementation of action plans, such as: (i) account standards (ii) management information systems including internal control and audit systems (iii) computerization plan (iv) human development plan for RCC.

PACS were also required to undergo special audits (to assess the extent of accumulated losses as of $31^{\text {st }}$ March 2004), based on uniform accounting criteria and implement plans to phase out cadre-based secretaries in PACSs for greater accountability in functioning of PACSs. Institutional reforms also sought for development and implementation of plans in participating states having ineligible PACS.

\section{C. $\quad$ Financial Package}

Financial package was a one-time conditional measure released only on the implementation of the recommendations for legal and institutional reforms with the objective of bringing PACS to an acceptable level of financial health through cleansing of their balance sheets and strengthening their capital base. The financial package was subject to specific conditions. The quantum of financial assistance for covering the accumulated losses of PACS as of $31^{\text {st }}$ March 2004 was determined on the basis of the uniform accounting standard. The special audit ensured that in the event of insufficient provisioning made by the RCC, they do not get undercapitalized. The package assistance initially allowed PACS to reach a minimum Capital to Risk Weighted Assets Ratio (CRAR) of 7 percent and within a span of three years increased to $9 \%$ to meet the minimum industry standards. All RCC were expected to meet the CRAR by such time.

With the new financial package, the share of the state government was aimed to bring down to below 25 percent of the total subscribed share capital within a period of three years. In case the share of State Government's equity was more than $25 \%$, the excess amount would be converted into a grant by the state government to the concerned RCC entity. There was strong emphasis on phasing out the State Government equity participation within a reasonable period of time. The revival package envisaged that financial restructuring would start with first bringing the PACSs to an acceptable level of financial health through cleaning of their balance sheets and strengthening their capital bases, and then moved to the upper tiers. This 
would enable PACSs to clear their dues to the upper tiers and thereby reduce the accumulated losses of DCCBs. The DCCBs would then be provided assistance to clear the balance of accumulated losses, if any, and to reach minimum capital adequacy norms. The same process would apply to SCBs.

\section{D. $\quad$ Eligibility Norms}

All PACS with a recovery level of at least $30 \%$ of the demand as on $30^{\text {th }}$ June 2004 were qualified for being covered under the revival package. State governments were obliged to determine the future set up of PACS having recovery levels of less than $30 \%$. State governments were required to take appropriate steps to ensure the flow of agricultural credit to farmers in the operational areas of such non-qualifying PACS.

PACS with recovery levels between $30 \%$ to $50 \%$ received financial assistance in three annual back-ended installments (at the beginning of each succeeding year), subject to their achieving an incremental increase in their recovery rate of at least 10 percentage points on $30^{\text {th }}$ June 2006 against the benchmark recovery achieved on $30^{\text {th }}$ June 2004, and with an annual increase of 10 percentage points thereafter. Full capitalization was provided to PACS with recovery levels of 50\% and above. As and when a PACS would achieve 50\% recovery, the entire financial assistance would be released without waiting for the year to year recovery benchmarks.

\section{Benchmarking And Status On Implementation}

Release of financial assistance under the financial package was linked to achievement of pre-defined benchmarks in respect of legal, institutional and regulatory reforms and therefore, was phased over a period [GoI, 2006]. Following is a summary of monitored benchmark activities under the package:

a. State Government accepts the package, issues consent letter, and signs the MOUs with GoI.

b. Assistance is provided for conduct of special audits, computerization and HRD initiatives of RCC.

c. PACS/DCCB/SCB sign MOUs with implementation committees, executive order amending necessary provisions in CSA issued by state government and after special audits are completed, state government releases committed liabilities.

d. $75 \%$ of financial assistance for funding the accumulated losses is released.

e. Elections are conducted wherever due, professionals are either elected or co-opted, professional CEO appointed, CSA amended or special chapter incorporated, a sound system of internal checks and controls put in place by SCBs/DCCBs and Development Action Plans/MOUs are signed.

f. Balance $25 \%$ of financial assistance for funding accumulated losses is released.

Since the implementation of the revival package in 2006, 25 state governments have entered into MoU for the revival of their respective short-term rural credit cooperatives. Subsequently, the amendments to the respective Cooperative Societies Acts and adoption of by-laws by the cooperatives have either been completed or are underway.

One of the most noticeable highlight under the reforms exercise has been the introduction of common accounting system [CAS] and management information system [MIS], and training to the staff and members of cooperatives to adopt these new practices. Over 90 percent of the RCC are currently involved in various stages of reforms and $63 \%$ of eligible PACS have received recapitalization from the governments, as shown in Table 1.

Table 1

Status on Implementation of Revival Package

\begin{tabular}{|c|l|l|}
\hline $\begin{array}{c}\text { Sr } \\
\text { No. }\end{array}$ & \multicolumn{1}{|c|}{ Reform Agenda } & \multicolumn{1}{c|}{ Implementation } \\
\hline 1 & Execution of MoUs & $\begin{array}{l}\text { 25 State Governments have signed the Memorandum of } \\
\text { Understanding (MoU) with GoI and NABARD, covering } \\
\text { more than 96\% of the RCC units in the country. }\end{array}$ \\
\hline 2 & Special Audit of PACS & $\begin{array}{l}\text { Out of the total 83,553 PACS, Special Audit has been } \\
\text { completed in 80,837 PACS [96.75\%]. }\end{array}$ \\
\hline 3 & $\begin{array}{l}\text { Amendments to Cooperative } \\
\text { Societies Act }\end{array}$ & $\begin{array}{l}21 \text { States have amended their respective State } \\
\text { Cooperative Societies Act through Legislative Process. }\end{array}$ \\
\hline 4 & $\begin{array}{l}\text { Amendments of Rules and } \\
\text { Adoption of Bye-laws }\end{array}$ & $\begin{array}{l}\text { Consequent to the amendment of the State Cooperative } \\
\text { Societies Act, 08 States have already amended their } \\
\text { respective State Cooperative Societies Rules in tune with } \\
\text { the amended Acts and the task is under progress in 13 } \\
\text { more States. } \\
\text { The bye laws of PACS have been amended in 10 States } \\
\text { and are in progress in 10 more States. } \\
\text { The process of amendment of Rules and bye-laws has } \\
\text { been initiated in other implementing States. }\end{array}$ \\
\hline
\end{tabular}


Reforms in Rural Credit Cooperatives in India

\begin{tabular}{|c|c|c|c|}
\hline$\overline{5}$ & $\begin{array}{l}\text { Status of Elected Board in } \\
\text { CCS Structure }\end{array}$ & \multicolumn{2}{|l|}{ 92\% PACS } \\
\hline 6 & HRD Training & \multicolumn{2}{|c|}{$\begin{array}{l}83,452 \text { PACS secretaries in } 21 \text { States. } \\
1,27,350 \text { elected members of PACS in } 18 \text { States. }\end{array}$} \\
\hline 7 & $\begin{array}{l}\text { Common Accounting System } \\
\text { (CAS) and } \\
\text { Management Information } \\
\text { System (MIS) for PACS }\end{array}$ & \multicolumn{2}{|c|}{$\begin{array}{l}\text { Training Module on CAS and MIS completed in } 76,237 \\
\text { PACS functionaries in } 19 \text { States. }\end{array}$} \\
\hline \multirow[t]{4}{*}{8} & \multirow{4}{*}{$\begin{array}{l}\text { Release of Recapitalization } \\
\text { Assistance in Eligible PACS }\end{array}$} & Number of PACS & $53204[63.68 \%]$ \\
\hline & & GoI Share & $78.43 \%$ \\
\hline & & State Government Share & $7.59 \%$ \\
\hline & & CCS Share & $13.97 \%$ \\
\hline
\end{tabular}

Source: NABARD [http://nabard.org/departments/highlights.asp]

\section{Performance Of Pacs}

What has been the response to the reform exercise being carried out in the largest rural financial system in the world? In order to assess the performance of the PACS before and over the post-reform period, certain performance indicators have been identified and evaluated over a period of twenty years from 1993-94 to 201011. The performance indicators have been compared for the following points of time: 1993-94 [the year for which earliest data were available pre-reform exercise]; 2003-04 [the year for which the special audits of PACS was carried out to find out the financial status of eligibility]; and 2010-11 [the latest year for which the aggregate national data was available]. The source of data is the National Federation of State Cooperative Banks Limited [NAFSCOB], Directory of PACS. NAFSCOB is the only agency involved in the collection and aggregation of the data on PACS at state and national level.

Table 2 presents the performance per PACS from the pre-reform period to the post-reform period. The membership per PACS has increased substantially and consistently over the three time periods from 972 in 1993-94 to 1281 in 2003-04 to as high as 1298 in the recent year of evaluation 2010-11. The number of borrowers declined in 2003-04 but later revived in 2010-11. The working capital of each PACS has multiplied manifold showing a tremendous growth from 17 lakhs in 1993-94 to almost 59 lakhs in 2003-04 and then shooting up to 154 lakhs in 2010-11. The reserves held per PACS have more than doubled over each time period of the study. Deposits and borrowings of the PACS have shown a significant expansion over the time periods. The same is also true for loans and advances issued and outstanding, and the amount of overdues per PACS.

Table 2

A Snapshot of the Performance of PACS: Pre and Post Reform Exercise

\begin{tabular}{|l|r|r|r|}
\hline \multicolumn{1}{|c|}{ Performance Per PACS } & $\mathbf{1 9 9 3 - 9 4}$ & $\mathbf{2 0 0 3 - 0 4}$ & \multicolumn{1}{c|}{$\mathbf{2 0 1 0 - 1 1}$} \\
\hline Membership & 972 & 1281 & 1298 \\
\hline Number of Borrowers & 552 & 485 & 561 \\
\hline Working Capital [in Rs. Lakhs] & 17.01 & 58.68 & 154.39 \\
\hline Reserves [in Rs. Lakhs] & 0.86 & 3.06 & 7.39 \\
\hline Deposits [in Rs. Lakhs] & 2.29 & 17.16 & 39.86 \\
\hline Borrowings [in Rs. Lakhs] & 9.95 & 32.39 & 57.81 \\
\hline Loan \& Advances Issued [in Rs. Lakhs] & 8.20 & 33.21 & 97.74 \\
\hline Loan \& Advances Outstanding [in Rs. Lakhs] & 11.50 & 41.49 & 93.96 \\
\hline Overdues [in Rs. Lakhs] & 4.57 & 15.41 & 24.29 \\
\hline Total Number of PACS & $\mathbf{9 1 , 5 9 2}$ & $\mathbf{1 0 5 , 7 3 5}$ & $\mathbf{9 3 , 4 1 3}$ \\
\hline
\end{tabular}

Source: NAFSCOB [http://www.nafscob.org/pacs_f.htm]

\section{References}

[1] ADB, India: Rural Cooperative Credit Restructuring and Development Program, Asian Development Bank, 2010.

[2] GoI, Package for Revival of Short Term Credit Cooperative Structure, Ministry of Finance, Government of India [GoI], 2006.

[3] Li and Parmar, Rural Credit Cooperatives in India, University of Virginia, Darden School of Business, Darden Case No. UVA-BP$0521,2007$.

[4] NAFSCOB, National Federation of State Cooperative Banks Limited, India, 2010

[5] Vaidynathan, Report of the Task Force on Revival of Rural Cooperative Credit Institutions, Government of India, Ministry of Finance, New Delhi, 2004. 